\title{
CRIMINAL PROCEDURE: SEARCHES INCIDENT TO A LAWFUL ARREST LIMITED TO THE AREA WITHIN REACH OF THE ARRESTEE
}

Drecipitating the revival of the long neglected search warrant, ${ }^{1}$ the Supreme Court in Chimel $v$. California ${ }^{2}$ held unlawful a warrantless search conducted incidental to the valid arrest of a coin store burglar, thereby expressly overruling the leading cases of Harris $v$. United States ${ }^{3}$ and United States $v$. Rabinowitz. Acting on information provided by a neighbor, three area police officers arrived at Ted Steven Chimel's home with an arrest warrant but without a search warrant. With the permission of Chimel's wife, they waited for him to return from work and upon his arrival effected the arrest. Although the arrest warrant was later determined to be insufficient, ${ }^{5}$ the arrest was held to be justified on the grounds that adequate probable cause was present. ${ }^{\circ}$ Notwithstanding Chimel's refusal to consent to a search of the house, the officers conducted a forty-five to sixty minute search throughout the entire three-room house on the theory that the search was incidental to a valid arrest. The search included the attic, garage and workshop, and purusant to the officer's directions, Chimel's wife moved articles in drawers to provide an unrestricted view of the contents. The officers seized coins, medals, and tokens which had presumably been taken in the burglary. Chimel attempted unsuccessfully to have these articles excluded at his trial on the grounds that the search was unconstitutional.

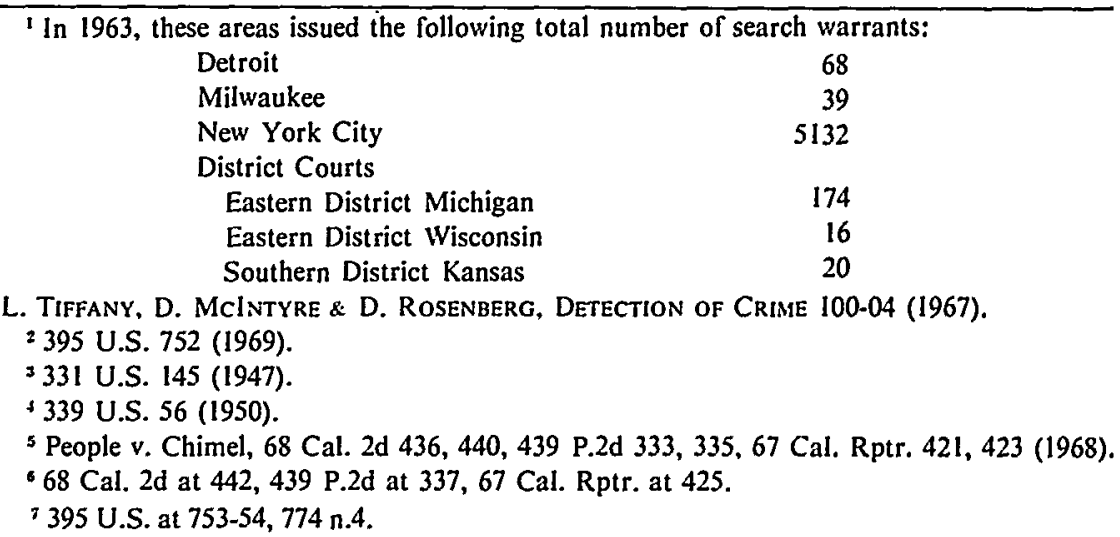


Because the fourth amendment was enacted in reaction to general warrants and searches during the colonial period, warrantless searches have never been favored. ${ }^{8}$ However, the Court has allowed warrantless searches incidental to a valid arrest on the basis of a need to safeguard arresting officers or to prevent the destruction of evidence. ${ }^{9}$ Such searches were ostensibly limited to the area within the arrestee's control, ${ }^{10}$ but the application of this ambiguous concept caused confusion and led the Court to adopt varied standards." First interpreted as including "the place of arrest," 12 control was found to-exist over a living-room and was later expanded to include "all parts of the premises used for an unlawful purpose." ${ }^{\prime 13}$ The latter interpretation provided the basis for admitting a ledger found in a closet while officers with a search warrant were seeking intoxicating liquors. ${ }^{14}$ Subsequently the Court evinced disapproval of this latitude and demanded search warrants if the police desired to extend searches of offices into safes and drawers, as occurred in Go-Bart Importing Co. v. United States ${ }^{15}$ and United States $v$. Lefkowitz. ${ }^{16}$ Finally, in Trupiano v. United States, ${ }^{17}$ the practicality of obtaining a warrant was made the leading factor in determining the reasonableness of a search. However, Harris departed from the rationale of these latter cases by approving a four-room search, the widest thus far condoned, and distinguished prior searches by indicating that in Harris the officers were not making an exploratory foray as in Go-Bart and Lefkowitz but rather were searching only for specific items. ${ }^{18}$ Placing

Id. at 761; see, e.g., Wong Sun v. United States, 371 U.S. 47I, 481-82 (1963); United States v. Jeffers, 342 U.S. 48, 51 (1951); United States v. Rabinowitz, 339 U.S. 56. 69 (1950) (Frankfurter, J., dissenting); McDonald v. United States, 335 U.S. 451, 455-56 (1948); Weeks v. United States, 232 U.S. 383, 390, 392 (1914); Boyd v. United States, 116 U.S. 616 (1886).

- See Preston v. United States, 376 U.S. 364, 367 (1964); United States v. Rabinowitz, 339 U.S. 56, 72 (1950) (Frankfurter, J., dissenting).

${ }^{10}$ See Carroll v. United States, 267 U.S. 132, 158 (1925).

" Compare United States v. Lefkowitz, 285 U.S. 452 (1932) with Harris v. United States, 331 U.S. 145 (1947).

12 Agnello v. United States, 269 U.S. 20, 46 (1925).

13 Marron v. United States, 275 U.S. 192, 199 (1927).

"Id. at 193.

is 282 U.S. 344 (1931).

16285 U.S. 452 (1932).

${ }^{17} 334$ U.S. 699 (1948).

is 331 U.S. at 153. 
emphasis on the fact that the evidence could hardly be ignored once it was found, the Court considered fortuitous the fact that the evidence that convicted Harris was not included in the warrant but was found during the search, as in Marron v. United States. ${ }^{10}$ Rabinowitz completed the liberalization begun by Harris by stating that the appropriate test was "not whether it is reasonable to procure a search warrant, but whether the search was reasonable."20 Thus by substituting the "totality of the circumstances," ${ }^{21}$ Trupiano's emphasis on the practicality of obtaining a warrant was removed from the determination of reasonableness.

An opposing line of authority that Chimel has now adopted was presaged by the dissents of Justice Jackson in Harris and Justice Frankfurter in Rabinowitz. Justice Jackson was opposed to allowing any search beyond the person of the arrestee, for to permit a wider latitude would lead to arbitrary distinctions and make any delineations impossible for the police. ${ }^{22}$ Frankfurter's dissent in Rabinowitz adopted a modification of this extreme view by allowing whatever was on the person and within his immediate control to be subject to search. ${ }^{23}$ Although the majority also used the term "immediate control," ${ }^{24}$ Frankfurter defined the term as including only what was in close physical proximity to the arrestee, not an area to which the person had an exclusive right. These dissenting views have been noticeably favored in recent Supreme Court decisions, with a consequent disregard for the majority holdings in Harris and Rabinowitz. ${ }^{25}$ Although doubting whether the Court in this decade would have decided Rabinowitz in the same manner, ${ }^{26}$ the lower federal courts have necessarily decided cases under its aegis, creating the possibility in several that opposite decisions would have been reached if Chimel had been the

19 275 U.S. 192 (1927).

${ }^{20} 339$ U.S. at 66.

${ }^{21}$ Id. at 63, 66. See also Ker v. California, 374 U.S. 23, 33 (1963).

2331 U.S. at 197.

27339 U.S. at 83.

${ }^{24} \mathrm{Id}$. at 61,64 (majority opinion).

25. See Warden v. Hayden, 387 U.S. 294, 299 (1967).

${ }^{25}$ See, e.g., United States v. Cruz, 265 F. Supp. 15, 25 (W.D. Tex. 1967); United States v. Williams, 219 F. Supp. 666 (S.D.N.Y. 1963), affd 336 F.2d 183 (2d Cir.), cert. denled, 379 U.S. 857 (1964). But see Niro v. United States, 388 F.2d 535 (1st Cir. 1968). 
law. ${ }^{27}$ Recent decisions of the Court in the related fourth amendment areas of "frisks" and eavesdropping had been used by some commentators ${ }^{28}$ as a basis for suggesting that Chimel was not only desirable, but inevitable. Katz $v$. United States ${ }^{29}$ went the farthcst in demanding warrants, stating that searches without warrants were "per se unreasonable,",30 while Terry v. Ohio ${ }^{31}$ held that only a limited external search of the person, motivated by reason to believe that the suspect is armed, is permissible.

After tracing the erratic "swings of the pendulum" in the field of warrantless searches, the Chimel Court proceeded to explain why the swing that produced Harris and Rabinowitz had been improper in the light of "historical" and "rational" analysis." Rabinowitz had not followed the precedent of its immediate forebears, GoBart, Lefkowitz and Trupiano, and had exaggerated the scope allowed in the cases it supposedly followed. More importantly, the Court observed that the limitless searches incident to an arrest allowed by Rabinowitz resembled the general searches which the fourth amendment was designed to destroy. ${ }^{33}$ The Court indicated that the older cases in the field qualified the right to search without a warrant by establishing standards which denominated the search legal if it met the requirements for a warrant. Additionally, the court indicated that cases such as Terry v. Ohio, ${ }^{34}$ Preston v. United States $^{35}$ and Warden v. Hayden ${ }^{36}$ all held that warrants should be obtained before a search is conducted and had severely limited the scope of permissible warrantless searches. Furthermore, the scrutiny of "rational" analysis gave no greater support than history to the test of Harris and Rabinowitz. Although Justice

${ }^{27}$ See, e.g., United States v. Cruz, 265 F. Supp. 15, 26 (W.D. Tex. 1967); United States v. Williams, 219 F. Supp. 666, 670 (S.D.N.Y. 1963), aff d, 336 F.2d 183 (2d Cir.), cert. denied, 379 U.S. 857 (1964).

${ }^{23}$ See, e.g., The Supreme Court, 1966 Term, 81 Harv. L. REv. 69, 117, 121 (1967); Comment, Search \& Seizure in the Supreme Court: Shadows on the Fourth Amendment, 28 U. CHI. L. REV. 664 (1961); Note, Scope Limitations for Searches Incident to Arrest, 78 YALE L.J. 433 (1969).

20389 U.S. 347 (1967).

so Id. at 357.

31392 U.S. 1 (1968).

32395 U.S. at 760.

w See 339 U.S. at $69-70$ (Frankfurter, J., dissenting); note 8 supra and accompanying text. .

s 392 U.S. 1 (1968). See text accompanying note 31 supra.

3s 376 U.S. 364 (1964).

3387 U.S. 294 (1967). 
White, in dissent, urged that the police here had independent probable cause sufficient for the search without having to rely upon the arrest for justification, the majority dismissed this contention on the basis that this was all the more reason for the police to have procured a warrant before the arrest was made. The Court also dismissed, as irrational, previous attempts to distinguish reasonable and unreasonable searches on such grounds as the number of rooms searched, or whether the arrest occurred inside or outside a house. The fears which prompted adoption of the fourth amendment and were expressed in Justice Frankfurter's dissent in Rabinowit ${ }^{37}$ were found to have been substantiated in past cases where searches have been conducted on trivial excuses. ${ }^{38}$ These fears are realized where the police purposely wait for a suspect to enter an area they desire to investigate before effecting an arrest. ${ }^{30}$ Although the Court did not expressly find this to have been true in Chimel, the possibility that this strategem was used is raised and offered as a further basis for overruling the Harris-Rabinowitz standard of reasonableness. Applying "sound Fourth Amendment principles" 40 the Court held that the search was unreasonable because it extended beyond the area now defined as immediate control-the extent of the arrestee's reach.

In addition to re-establishing the search warrant as a major aspect of criminal procedure, Chimel provides a realistic guideline for the police. Previously a search was evaluated on its "reasonableness" as seen in the total context of the case. This nebulous concept gave the police no assistance since they interpreted Rabinowitz as allowing a thorough examination of virtually the entire premises..$^{41} \ln$ general the courts acquiesced ${ }^{12}$ and admitted the fruits of questionable searches because of the impossibility of determining "reasonableness." Therefore it was held that if the person had a legal right to the premises, be it an

${ }^{37} 339$ U.S. at 80-82. (Frankfurter, J., dissenting).

38 See, e.g., Abel v. United States, 362 U.S. 217 (1960); Lofton v. WVarden, 83 Nev. 356, 431 P.2d 981 (1967). See also United States v. Kirschenblatt, 16 F.2d 202, 203 (2d Cir. 1926).

${ }^{39}$ E.g., Agnello v. United States, 269 U.S. 20 (1925); McKnight v. United Stutes, 183 F.2d 977 (D.C. Cir. 1950).

t0 395 U.S. at 768.

"See, e.g.. People v. Braden, 34 III. 2d 516, 216 N.E.2d 808 (1966); State v. Miller, 47 N.J. 273, 220 A.2d 409 (1966).

${ }^{42}$ See cases cited note 41 supra. 
office or a boarding-room, ${ }^{43}$ and if he were present at the time of arrest, the area was in his immediate control. ${ }^{44}$ Chimel, by definitely stating that immediate control includes only that area in which the arrestee might have been able to gain access to a weapon or destructible evidence, ${ }^{45}$ broadens the chances for future exclusions due to an overwide search. Justice White argued that in addition to the limited emergencies recognized by the Court in which a warrant would be unnecessary, ${ }^{46}$ the arrest itself created an emergency situation in which evidence could have been destroyed before the return of the officers, but the majority placed emphasis upon the fact that the officers possessed an arrest warrant and therefore could have procured a search warrant at the same time. There are ways to prevent the destruction that Justice White envisioned, in stituations where officers find it necessary to return to the magistrate, such as sealing the room, placing the other occupants under police surveillance, or even removing them. It does not seem unduly burdensome to require a police officer to apply for a search warrant at the same time he procures an arrest warrant. This encourages the constitutional preference for objective intervention by a magistrate to determine the reasonableness of the search. If the magistrate, in issuing a search warrant, requires more than a finding of probable cause to arrest, and if the search warrant is not automatically issued in conjunction with a warrant for arrest, Chimel will contribute to the prevention of unsanctioned invasions of privacy and reduce the necessity of resorting to the exclusionary rule.

Further, although Chimel may increase dependence upon consent searches, the decision will likely increase the importance of recent cases dealing with requirements for a valid warrant, ${ }^{17}$ which

\footnotetext{
"See, e.g., United States v. Rabinowitz, 339 U.S. 56 (1950); Haas v. United States, 344 F.2d 56 (8th Cir. 1965).

"See, e.g., Harris v. United States, 331 U.S. 145 (1947); United States v. Cole, 365 F.2d 57 (7th Cir. 1966), cert. denied, 385 U.S. 1027 (1967); Haas v. United States, 344 F.2d 56 (8th Cir. 1955).

${ }^{15} 395$ U.S. at 763. For a recent application of this test, see People v. Cressy, 275 Cal. App. 2d 603, 80 Cal. Rptr. 65 (1969), where a gun and an envelope of marijuana on a table 10 to 15 feet from defendant were held to be in his control.

${ }^{15}$ See, e.g., Katz v. United States, 389 U.S. 347, 357 n. 19 (1967); Warden v. Hayden, 387 U.S. 294 (1967); Sehmerber v. California, 384 U.S. 757 (1966); Carroll v. United States, 267 U.S. 132 (1925).

${ }^{17}$ See, e.g., Spinelli v. United States, 393 U.S. 410 (1969); United States v. Ventresca, 380 U.S. 102 (1965); Agnello v. United States, 269 U.S. 20 (1925).
} 
have previously had only a limited impact due to the reliance of the police on search incident to arrest. Chimel, although probably destined to be the object of criticism by those feeling that another heavy burden has been added to policework, ${ }^{48}$ places the search incident to arrest in its proper perspective as a limited emergency protective measure rather than an excuse for full-scale explorations which would otherwise be prohibited by the fourth amendment.

\footnotetext{
${ }^{18}$ To date, Chimel has been applied prospectively only. See People v. Groves, 458 P.2d 985, 80 Cal. Rptr. 745 (1969); People v. Edwards, 458 P.2d 713, 80 Cal. Rptr. 633 (1969); People v. Superior Ct., 81 Cal. Rptr. 42,47 (Ct. App. 1969); People v. Chambers, 80 Cal. Rptr. 672 (Ct. App. 1969); People v. Castillo, 80 Cal. Rptr. 211 (Ct. App. 1969); People v. Cressy, 80 Cal. Rptr. 65 (Ct. App. 1969); People v. Foster, 79 Cal. Rptr. 397 (Ct. App. 1969); Scott v. State, 256 A.2d 384 (Md. App. 1969); cf. Colosimo v. Perini, No. 18832 (6th Cir., Sept. 17, 1969).
} 